\title{
Employee involvement, job satisfaction, and in-role performance
}

\author{
Nikodemus Hans Setiadi Wijaya ${ }^{1}$, Diaz Haryokusumo ${ }^{1}$, and Muhammad Dian Akbar ${ }^{1}$ \\ ${ }^{1}$ Department of Management, Sekolah Tinggi IImu Ekonomi YKPN, Indonesia
}

\begin{tabular}{ll}
\hline Abstract & This study examines the relations among employee involvement, job satisfaction, and in- \\
role performance. Job satisfaction is posited as a mediator. A total of 102 respondents filled \\
out a self-administrated survey. The hierarchical regression analysis was performed to test \\
the direct influence hypotheses. To carry out the mediation test, the procedures proposed \\
by Baron and Kenny and the Sobel Test to strengthen were both used. It was found that the \\
influence of employee involvement variables was positive on job satisfaction and in-role \\
performance. Results also showed a positive of job satisfaction on in-role performance. Job \\
satisfaction partially mediated the relationship between employee involvement and in-role \\
performance. Implications of the findings, implications, and limitations are discussed.
\end{tabular}

\section{INTRODUCTION}

Employee performance is very significant for organizations because it supports organizational performance. On the contrary, poor employee performance becomes a hindering factor to organizational effectiveness. In today's competitive business environment, companies need to improve the employee to increase goal achievement possibility.

Performance (sometimes called work performance) can be defined as the result of carrying out a job done by an individual, in accordance with the responsibilities that have to be carried out, which is helpful for the organization to achieve its goals, mission, and vision (Timpe, 2002). Similarly, Douglas (2000) argues that the company's high job performance is needed by the company (Mariam, 2009). According to Indriyani and Wisnu (2010), high performance is one of the roles of human resources to support company goals (Giantari \& Riana, 2017).

A critical dimension of performance is inrole performance (or in other sources also labeled as "in-role behavior") is the achievement reached by individuals in completing work that is explicitly written in the job description (Williams \& Anderson, 1991). This study proposes a perspective on how employee involvement may affect job satisfaction and in-role performance.
Employee involvement is the level of employee participation in making decisions, the perception that his/her ideas and views are taken into account, and how managers encourage employees to give their opinions (Glaser, 1897). Glaser also argues that engaging employees is one of the dimensions of organizational culture that creates a positive atmosphere.

Job satisfaction refers to the general attitude of employees towards work, systems, procedures, and work environment (Judge, Heller, \& Klinger, 2008; Wijaya, 2019). Job satisfaction has been found as an attitude in the job that significantly influences employee behavior and performance. A satisfied employee characterizes when they are happy with their duties, responsibilities, and other organizational factors such as leadership style, co-worker support that match with employees' expectations. This attitude may boost better employee performance (Williams \& Anderson, 1991).

The proposed model is in Figure 1. It depicts the relationships among employee involvement, job satisfaction, and in-role performance. The study data was taken from one of an automotive company operating in Yogyakarta.

This company operates the distribution and retail sales of two-wheeled vehicles under one of an international automotive brand. The findings of this study should offer organizational managers by depicting the importance of employee involvement and 
Figure 1.

Proposed model

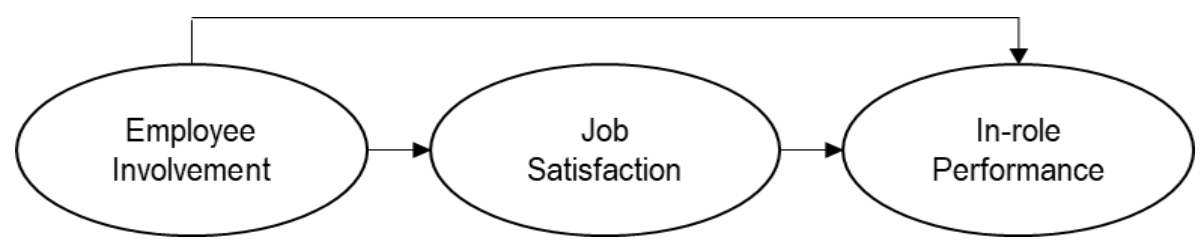

job satisfaction in encouraging in-role performance.

\section{LITERATURE REVIEW AND HYPOTHESES DEVELOPMENT}

\section{Job involvement, job satisfaction, and in-role performance}

According to William and Anderson (1991), in-role performance measures the extent to which an employee can carry out the main activities listed in the job description. According to Abdulloh (2006), this performance describes the capabilities and achievements of employees according to specific criteria determined by the company or in accordance with their responsibilities. As mentioned above, job participation represents to what extent an employee can make decisions and provide ideas for other parties in the organization (Glaser, 1897). Judge, Heller, and Mount (2002) posit that job satisfaction is an attitude that are promoted by various working aspects in the organization.

It is believed that when the perception of involvement is high, employees will feel satisfied with their work because of the appreciation they receive. Past research argued that when organizations encourage employees to involve in the decision-making process and to be able to express opinions, they will be motivated to apply it in real action in their work practices (Rees, Alfes, \& Gatenby, 2013), thus encouraging higher inrole performance. When employees perceive they have high involvement in the workplace, their in-role performance and job satisfaction will be increased. Therefore, the following hypotheses are formulated:

\section{H1: Employee involvement is positively related to in-role performance.}

H2: Employee involvement is positively related to job satisfaction.

\section{Job satisfaction and in-role performance}

Job satisfaction is an attitude in employees that can promote various expected behaviors (Whitman, Van Rooy, \& Viswesvaran, 2010; Wijaya, 2019), specifically in-role performance (Williams \& Anderson, 1991). Therefore, job satisfaction is an essential attitude for employees, teams, and organizations. If job satisfaction increases, it will promote higher work morale, dedication, loyalty, and employee discipline. Robbins and Judge (2011) argue that several job aspects can affect employee job satisfaction, namely the job itself, specific skills needed to carry out a job, supervisory, co-worker support, promotion opportunities, and salary level.

Job satisfaction can play a role as a critical driving force for increasing job performance. In general, employees who have a positive attitude towards their work and other work elements will be motivated to improve their effort (Judge, Thoresen, Bono, \& Patton, 2001). Optimal job performance can be achieved if high job satisfaction is met (Indrawati, 2013; Khuzaeni \& Djumahir, 2013). Based on the discussion above, the following hypothesis is formulated:

H3: Job satisfaction is positively related to in-role performance.

\section{Job satisfaction as a mediator}

Following the proposed research model, job satisfaction can play a role as a mediator in the relationship between employee involvement and in-role performance. The perception of employee involvement will affect the levels of employee satisfaction, in turn, the levels of in-role performance. Therefore, the following hypothesis is formulated:

H4: Job satisfaction mediates the positive relationship between employee involvement and in-role performance. 
Table 1.

Respondent characteristics

\begin{tabular}{llcc}
\hline Characteristics & \multicolumn{1}{c}{ Groups } & Freq. & $\%$ \\
\hline Education Level & High School & 59 & $57,84^{*}$ \\
& Diploma & 10 & 9,80 \\
& Undergraduate & 33 & 32,35 \\
& Master's & 0 & 0,00 \\
& Total & $\mathbf{1 0 2}$ & $\mathbf{1 0 0 , 0 0}$ \\
\hline Gender & Male & 69 & $67,65^{*}$ \\
& Female & 33 & 32,35 \\
& Total & $\mathbf{1 0 2}$ & $\mathbf{1 0 0 , 0 0}$ \\
\hline Age & $17-24$ & 39 & $38,24^{*}$ \\
& $25-31$ & 37 & 36,27 \\
& $32-38$ & 17 & 16,67 \\
& $39-45$ & 9 & 8,82 \\
& Total & $\mathbf{1 0 2}$ & $\mathbf{1 0 0 , 0 0}$ \\
\hline Tenure (in years) & $0-2$ & 42 & $41,18^{*}$ \\
& $>2-5$ & 28 & 27,45 \\
& $>5-10$ & 26 & 25,49 \\
& $>10$ & 6 & 5,88 \\
& Total & $\mathbf{1 0 2}$ & $\mathbf{1 0 0 , 0 0}$ \\
\hline
\end{tabular}

*highest percentage

\section{METHODS}

\section{Respondent characteristics}

Respondents in this study were employees of a branch of the national automotive industry company, namely the Honda Sales Operation (HSO) Astra Motor Yogyakarta. A paper-based questionnaire was used in data collection. The Human Resource Management Department of the company assisted in distributing the questionnaire. A total of 150 pieces were distributed. Eventually, 102 employees gave responses. The samples were all usable. Table 1 shows that most respondents completed high school education (57.84\%), were male $(67.65 \%)$, and in the age interval group of $17-24$ years (38.24\%). The work period for 0-2 years dominated the respondents $(41.18 \%)$. The distribution of respondent characteristics can be seen in table 1 .

\section{Measurement}

The research instruments employed a 5point Likert scale from strongly disagree (1) to strongly agree (5). Before testing the hypothesis, the validity and reliability of the research instrument were firstly tested. Factor analysis is used to test the validity of the instruments. Statement items will be dropped if they have a factor loading of less than 0.5 . The reliability was measured with Cronbach's alpha.
The research instruments in this study were previously developed and validated other research. Employee involvement was measured using the psychometric dimensions developed by Glaser (1897) (i.e., Organizational Culture Survey or OCS). This scale consists of four items. The factor loadings for the items were between 0.680.81 . Cronbach's alpha for this scale was 0.76 . A sample item is "This organization values workers' ideas at all levels."

Job satisfaction was measured using a 3item scale developed by The Michigan Organizational Assessment Questionnaire and revalidated by Zhou and George (2001). The factor loadings were between $0.80-$ 0.84 . Cronbach's alpha for this scale was 0.75. A sample item is "Overall, I am satisfied with my job." Lastly, in-role performance was measured using the 7point scale of in-role performance developed by Williams and Anderson (1991). The factor loadings for the items were between 0.550.81 . Cronbach's alpha for this scale was 0.83. A sample item is "I complete the responsibilities specified in the job description."

There were two variables involved in the analysis to control for the effect of the independent variable on the dependent, namely education and organizational tenure. The highest education of a person can affect the level of job satisfaction and employee performance. The longer they work, the deeper the employee experience in doing 
Table 2.

Descriptive statistic and correlations ${ }^{\mathrm{a}}$

\begin{tabular}{lccccccc}
\hline \multicolumn{1}{c}{ Variables } & Mean & s.d. & $\mathbf{1}$ & $\mathbf{2}$ & $\mathbf{3}$ & $\mathbf{4}$ & $\mathbf{5}$ \\
\hline 1. Education & 1,75 & 0,92 & & & & & \\
2. Tenure & 1,95 & 0,95 & 0,10 & & & & \\
3. Employee Involvement & 3,80 & 0,54 & 0,14 & 0,11 & $(0,76)$ & & \\
4. Job Satisfaction & 4,10 & 0,58 & 0,10 & $-0,05$ & $0,55^{\star \star}$ & $(0,75)$ & \\
5. In-role performance & 4,05 & 0,42 & 0,17 & $0,27^{\star *}$ & $0,59^{\star \star}$ & $0,54^{\star *}$ & $(0,83)$ \\
\hline
\end{tabular}
a $\mathrm{N}=102 ;$ s.d. = standard deviation; ${ }^{*} \mathrm{p}<.05,{ }^{*} \mathrm{p}<.01$. Cronbach alpha coefficient are listed in the diagonal in parentheses

his/her tasks, in turn affecting job satisfaction and performance.

\section{RESULTS AND DISCUSSION}

Table 2 shows the descriptive statistics (mean and standard deviation) and the correlation coefficients. It is shown that employee involvement, job satisfaction, and in-role performance are correlated with one another.

As shown in table 2, the respondents had an average of 1.95 years of work experience. Overall, respondents had high perceptual scores for involvement, job satisfaction, and in-role performance (note: the average value of the three variables was more than 3.5; employee involvement = 3.80 ; job satisfaction $=4.10$; in-role performance $=4.05$ ).

Only organizational tenure had a positive correlation with in-role performance. The coefficient coefficients among the main variables ranged from 0.27 to $0.59(p<0.01)$. They were considered "mediocre" in magnitude. Thus no severe multicollinearity was found.

The hierarchical regression analysis was used to test the proposed hypotheses. This analysis can measure changes in F-value and R-squared with the addition of a variable or variables in a model. First, the control variable was regressed to in-role performance. As seen in Model 1, the effect of organizational tenure was positive $(0.25$; $\mathrm{p}<0.01)$. Hypothesis $1(\mathrm{H} 1)$ predicts a positive effect of employee involvement on in-role performance. Model 2 shows that the regression coefficient of employee involvement in in-role performance is 0.56 ( $p$ $<0.001$ ). H1 was supported. Hypothesis 2 $(\mathrm{H} 2)$ states that there is a positive effect of employee involvement on job satisfaction. Model 3 shows the coefficient in accordance with the predictions $(0,56 ; \mathrm{p}<0.001)$. H2 was supported. Furthermore, Hypothesis 3 (H3) proposes a positive effect of job satisfaction on in-role performance. The regression coefficient of job satisfaction on in-role performance was also predicted (0.55; $p<0.001$, Model 4). Therefore, H3 was also supported.

Baron and Kenny (1986) propose that several conditions must be passed to evaluate the mediating effect. Condition 1 is that the independent variable (employee involvement) must significantly influence the independent variable (in-role performance). The second condition is that the independent variable must significantly influence the mediating variable (job satisfaction). Third, the mediating variable must influence the dependent variable. Table 3 shows that all three conditions have been achieved. Hypothesis $4(\mathrm{H} 4)$ states that job satisfaction mediates the relationship between employee involvement and supported in-role performance. Condition 4 is to evaluate the nature of the mediation. The independent and mediated variables are regressed together on the dependent variable. If the effect of the independent variable on the dependent remains significant, but its strength decreases, then the nature of the mediation is partial. However, on the contrary, if the independent variable on the dependent is no longer significant, then the nature of the mediation is full. Model 5 shows that the effect of employee involvement on in-role performance was still significant $(0.36$; $p$ $<0.001$ ) but decreased in the strength (see Model 2). Therefore, the mediating nature of job satisfaction was partial.

To complete the previous mediation test procedure, this study also performed the Sobel This validated whether the indirect effect of employee involvement on in-role performance through job satisfaction 
Table 3.

Regression analysis results ${ }^{b}$

\begin{tabular}{|c|c|c|c|c|c|}
\hline Variabel & $\begin{array}{l}\text { Model } \\
\quad 1\end{array}$ & $\begin{array}{c}\text { Model } 2 \text { (H1) } \\
\text { Involvement } \\
\overrightarrow{\text { IRP }}\end{array}$ & $\begin{array}{c}\text { Model } 3 \text { (H2) } \\
\text { Involvement } \\
\vec{\rightarrow} \\
\text { Satisfaction }\end{array}$ & $\begin{array}{c}\text { Model } 4 \\
(\mathrm{H} 3) \\
\text { Satisfactio } \\
n \rightarrow \text { IRP }\end{array}$ & $\begin{array}{c}\text { Model } 5 \text { (H4) } \\
\text { Involvement, } \\
\text { Satisfaction } \\
\rightarrow \text { IRP }\end{array}$ \\
\hline 1. Education & .15 & .07 & .03 & .09 & .06 \\
\hline 2. Tenure & $.25^{\star *}$ & $.20^{*}$ & -.12 & $.29^{\star \star \star}$ & $.24^{\star *}$ \\
\hline $\begin{array}{l}\text { 3. Employee } \\
\text { Involvement }\end{array}$ & & $.56^{\star \star \star}$ & $.56^{\star *}$ & & $.36^{\star \star \star}$ \\
\hline 4. Job Satisfaction & & & & $.55^{\star \star *}$ & $.35^{\star \star *}$ \\
\hline F-value & $5.01^{\star \star \star}$ & $21.19^{\star \star \star}$ & $15.01^{\star \star \star}$ & $20.51^{\star \star \star}$ & $21.95^{\star \star \star}$ \\
\hline $\mathbf{R}^{2}$ & .08 & .38 & .39 & .52 & .48 \\
\hline Adj. $R^{2}$ & .08 & .38 & .37 & .48 & .45 \\
\hline
\end{tabular}

Table 4.

Sobel, Aroian, and Goodman test for mediation testing

\begin{tabular}{lcc}
\hline \multicolumn{1}{c}{ Test } & Test Statistic & P-value \\
\hline Sobel Test & 3,56 & 0,00 \\
\hline Aroian Test & 3,52 & 0,00 \\
\hline Goodman Test & 3,58 & 0,00 \\
\hline
\end{tabular}

existed. Furthermore, the Aroian test and the Goodman test were used to confirm the Sobel test results. Table 4 shows the results of the calculation of the Sobel test (Z-value $=3.56 ; \mathrm{p}<0.00)$. These results also confirmed previous results, suggesting a potential role of mediating job satisfaction in the relationship between employee involvement in the in-role performance.

\section{CONCLUSION}

Based on hypotheses testing and data analysis that has been previously described, it formulates several conclusions. Employee involvement has a positive effect on in-role performance. The higher the employee involvement, the higher the employee performance. These results are in line with previous research such as the study conducted by Mohsan et al. (2011), Islam et al. (2012), as well as Satavuthi and Chaipoopirutana (2014). The results from Islam et al. (2012) showed that job involvement positively affected in-role performance; this indicates that individuals who experience high involvement are more likely to have better performance.

Other findings indicate that employee involvement has a positive effect on employee job satisfaction. The higher the level of employee involvement in the workplace, the higher the job satisfaction will be. Similar findings were discovered from previous research. Garcia et al. (2018) found a positive influence of job involvement and job satisfaction on performance. When employees can take a large portion of involvement in the workplace, a sense of satisfaction with the workplace will be developed (Garcia et al., 2018).

Job satisfaction has a positive effect on in-role performance. The higher the job satisfaction felt by the employee, the more they willing to perform their written tasks. These findings are supported by previous findings by Satavuthi and Chaipoopirutana (2014). They also found a positive effect of job satisfaction on in-role performance.

The current study also found the mediating role of job satisfaction. Job involvement can promote in-role performance indirectly via job satisfaction. Empirically, this study provides a shred of additional evidence and theoretical support for the relationship between involvement, satisfaction, and performance. In addition, the research context used (an automotive service company located in Indonesia, especially Yogyakarta) may strengthen the external validity of the empirical application because this study used a different study context from the extant works. 
We realize that there are still several limitations of this research. First, the respondents filled out all the measurement items. This could be a potential source of common method bias. In addition, job satisfaction was found to mediate the relationship partially, yet the evidence of mediating effect was not strong. Further research can replicate the findings to explore the nature of the relationship among the variables. It is suggested that future research can explore different contexts of samples. Since the current research only focused on one industrial/organizational background, it may lack generalizability. It may enrich the insights about the relationships among employee involvement, satisfaction, and performance.

\section{REFERENCES}

Abdulloh. (2006). Pengaruh Budaya organisasi, Locus Of Control dan Kepuasan Kerja Terhadap Kinerja Karyawan pada Kantor Pelayanan Pajak Semarang Barat. (Masters Tesis), Universitas Diponegoro, Semarang. http://eprints.undip.ac.id/15153/

Baron, R. M., \& Kenny, D. A. (1986). The moderator-mediator variable distinction in social psychological research: Conceptual, strategic, and statistical considerations. Journal of Personality and Social Psychology, 51(6), 11731182.

Douglas, Alan, V.S. (2009). Interactions between Corporate Agency Conflicts. The Financial Review, 44(2), 151-178.

Garcia, Gustavo., A., Gonzales-Miranda, Diego Rene., Gallo, Oscar., \& RomanCalderon, Juan Pablo. (2018) Employee Involvement and Job Satisfaction: a Tale of The Millenial Generation. Employee Relations: The International Journal, 41(3), 374-399.

Giantari, I. A. I., \& Riana, I. G. (2017). Pengaruh Budaya Organisasi terhadap Motivasi Kerja dan Kinerja Karyawan Klumpu Bali Resort Sanur. Manajemen Unud, 6(12), 6472 - 6498.

Glaser, S. (1897). Measuring and interpreting organizational culture. Management Communication Quarterly, 1(2), 173298.

Indrawati, A. D. (2013). Pengaruh Kepuasan Kerja Terhadap Kinerja Karyawan dan Kepuasan Pelanggan Pada Rumah Sakit Swasta di Kota Denpasar.
Manajemen, Strategi Bisnis, dan Kewirausahaan, 7(2), 135-142.

Indriyani, Etty \& Wisnu, Haryanto Petrus Christologus. (2010). Pengaruh Budaya Organisasi Dan Kepuasan Kerja Terhadap Kinerja Karyawan Dengan Komitmen Organisasi Sebagai Variabel Intervening Pada Workshop SMK Katolik Santo Mikael Surakarta. Jurnal Manajemen Excelent, 1(1), 1-10.

Islam, T., Khan, S.U.R., Ahmad, U.N.U., \& Ahmed, I. (2012). Does organisational commitment enhance the relationship between job involvement and inrole performance? SA Journal of Human Resource Management/SA Tydskrif vir Menslikehulpbronbestuur, 10(2), Art. \#460, 9 pages. http://dx.doi.org/10.4102/sajhrm.v10i2.4 60

Judge, T. A., Heller, D., \& Klinger, R. (2008). The dispositional sources of job satisfaction: A comparative test. Applied Psychology: An International Review, 57(3), 361-372.

Judge, T. A., Heller, D., \& Mount, M. K. (2002). Five-factor model of personality and job satisfaction: A meta-analysis. Journal of Applied Psychology, 87(3), 530-541. doi:10.1037/0033-2909.124.2.197

Judge, T. A., Thoresen, C. J., Bono, J. E., \& Patton, G. K. (2001). The job satisfaction-job performance relationship: A qualitative and quantitative review. Psychological Bulletin, 127(3), 376-407.

Khuzaeni, M. I., \& Djumahir, S. (2013). The Influence of Work Culture, Work Stress to the Job Satisfaction and Employees Performance in the State Treasury Service Office in Jakarta, Indonesia. IOSR Journal of Business and Management, 9(2), 49-54.

Mariam, R. (2009). Pengaruh Gaya Kepemimpinan dan Budaya Organisasi terhadap Kinerja Karyawan Melalui Kepuasan Kerja Karyawan Sebagai Variabel Intervening Studi Pada Kantor Pusat PT.Asuransi Jasa Indonesia (Persero). (Masters Tesis), Universitas Diponegoro, Semarang.

Mohsan, F., Nawaz, M.M., Khan, M.S., Shaukat, Z., Islam, T., Aslam, N. et al. (2011). Impact of job involvement on organisational citizenship behavior (OCB) and inrole job performance: A Study on banking sector of Pakistan. European Journal of Social Sciences, 24(4), 494-502. 
Rees, C., Alfes, K., \& Gatenby, M. (2013). Employee voice and engagement: Connections and consequences. The International Journal of Human Resource Management, 24(14), 27802798.

Robbins, S. P., \& Judge, T. A. (2011). Organizational Behavior. New Jersey: Pearson.

Satavuthi, Thanun., \& Chaipoopirutana, Sirion. (2014). The Exploration of the Factors Affecting on In-Role Job Performance: A Case Study for Thai Nondestructive Testing Public Company Limited's Employees. International Conference on Business, Law and Corporate Social Responsibility (ICBLCSR'14) Oct 1-2, 2014 Phuket (Thailand).

Timpe, A. D. (2002). Kinerja (S. Cikmat, Trans. 1 ed.). Jakarta: Elex Media Komputindo.

Whitman, D. S., Van Rooy, D. L., \& Viswesvaran, C. (2010). Satisfaction, citizenship behaviors, and performance in work units: A meta-analysis of collective construct relations. Personnel Psychology, 63(1), 41-81. doi:10.1111/j.1744-6570.2009.01162.x

Wijaya, N. H. S. (2019). Linking job dissatisfaction, learning motivation, creative work involvement, and proactive personality. Problems and Perspectives in Management, 17(1), 3241.

Williams, L. J., \& Anderson, S. E. (1991). Job satisfaction and organizational commitment as predictors of organizational citizenship and in-role behaviors. Journal of Management, 17(3), 601.

Zhou, J., \& George, J. M. (2001). When job dissatisfaction leads to creativity: Encouraging the expression of voice. Academy of Management Journal, 44(4), 682-696. 